\title{
Structural, thermal behaviour and vibrational study of a new mixed cesium-ammonium tellurate
}

\author{
WAFA BEN ARIBIA ${ }^{\mathrm{a}}$, MAKKI ABDELMOULEH ${ }^{\mathrm{a}}$, VAN DER LEE $^{\mathrm{b}}$ \\ and AHLEM KABADOU ${ }^{\mathrm{a}, *}$ \\ a'Laboratoire de Sciences des Matériaux et de 1'environnement, Faculté des Sciences de Sfax, Université de \\ Sfax, BP 1171, 3000 Sfax, Tunisia \\ b Institut Européen des Membranes (UMR 5635), Université de Montpellier II, cc 047, Place E. Montpellier, \\ France \\ e-mail: ahlemkabadou@yahoo.fr
}

MS received 7 March 2011; revised 16 July 2011; accepted 28 July 2011

\begin{abstract}
Synthesis, crystal structure, thermal characterization, FTIR and Raman measurements are given for a new mixed compound cesium-ammonium tellurate. X-ray study showed that the $\left[\mathrm{Cs}_{0.92}\left(\mathrm{NH}_{4}\right)_{0.08}\right]_{2} \mathrm{TeCl}_{4} \mathrm{Br}_{2}$ compound crystallizes in the tetragonal space group $\mathrm{P} 4 / \mathrm{mnc}$, with a $=7.452$ (1) $\AA$, c $=10.544$ (3) $\AA$ and $\mathrm{Z}=2$. The refinement converged at room temperature to $R_{p}=0.093$ and $R_{w p}=0.076$. The structure is considered as isolated octahedral $\mathrm{TeCl}_{4} \mathrm{Br}_{2}^{2-}$. These anions show a $4^{\circ}$ rotation around the fourfold axis against the cubic arrangement of the $\mathrm{K}_{2} \mathrm{PtCI}_{6}$ type structure. The monovalent cations $\left(\mathrm{Cs}^{+} / \mathrm{NH}_{4}^{+}\right)$are located between the octahedra ensuring the stability of the structure by ionic and hydrogen bonding contacts: $\mathrm{Cs}$... $\mathrm{Cl} / \mathrm{Br}$ and $\mathrm{N}-\mathrm{H} . \ldots . \mathrm{Cl} / \mathrm{Br}$. A DTA/TGA experiment at high temperature reveals one endothermic peak at $780 \mathrm{~K}$ for this compound. At low temperature a transition from phase I to phase II was detected at $213 \mathrm{~K}$ by DSC. This transition, confirmed by Raman analysis, can be attributed to an order-disorder phase transition.
\end{abstract}

Keywords. Crystal growth; X-ray diffraction; crystal structure; Raman spectroscopy.

\section{Introduction}

In 1957, Gillespie and Nyholm ${ }^{1}$ developed the valence shell electron-pair repulsion theory, according to which the lone pair of electrons present in, for example, the hexachlorotellurate(IV) complex anion should be stereochemically active and distort the coordination polyhedron from being regular octahedral.

The structure of tellurium materials has been extremely popular in recent years due to the peculiar electronic configurations of tellurium IV, whose electron lone pair induces several coordinations and unusual structures. ${ }^{2-4}$

However, The $\mathrm{A}_{2} \mathrm{TeX}_{6}$ family (A being alkali metal and $\mathrm{X}$ a halogen) represents also a vast class of semiconductors. They have been attracting considerable attention because of their potential applications in optical modulation and scanning devices. ${ }^{5}$

For compounds $\mathrm{A}_{2} \mathrm{TeBr}_{6}$ (with $\mathrm{A}=\mathrm{K}, \mathrm{NH}_{4}, \mathrm{Rb}$, $\mathrm{Cs})^{6-8}$ the high-temperature phases show the cubic $\mathrm{K}_{2} \mathrm{PtCl}_{6}$ type structure. Lowering the temperature, second order phase transitions can be observed, especially when the anions are comparatively large. These phase

*For correspondence transitions can be explained by a softening of rotary phonons. Generally, in $\mathrm{A}_{2} \mathrm{MX}_{6}$ compounds this instability is a result of a double minimum in the Coulomb potential with respect to the octahedra tilt angle $\varphi$ around (llll $\left.\begin{array}{lll}0 & 1\end{array}\right)$; the depth of this minimum depends on the interaction study ${ }^{9}$ which give us a hint for understanding the lattice dynamics of $\mathrm{A}_{2} \mathrm{MX}_{6}$ phases.

For investigating the sample dynamics, the degree of disorder in the different phases and the mechanisms involved in the transition with temperature, Raman scattering provides a powerful tool. Raman scattering measurements on $\left[\mathrm{Cs}_{0.92}\left(\mathrm{NH}_{4}\right)_{0.08}\right]_{2} \mathrm{TeCl}_{4} \mathrm{Br}_{2}$ material taken between $120 \mathrm{~K}$ and $400 \mathrm{~K}$ are reported in this paper.

\section{Experimental}

\subsection{Synthesis of sample and characterization}

Tellurium dioxide $\left(\mathrm{TeO}_{2}\right)$ was dissolved in the minimum amount of concentrated hydrochloric acid by heating. Two separate solutions of ammonium bromide and cesium bromide were prepared, then slowly and simultaneously added to the first solution (if a 
precipitate formed, it was reheated until dissolution). A few drops of concentrated hydrochloric acid were added to the hot solution until there was a permanent precipitate. The new mixed powder was filtered and stored in a desiccator containing a small beaker of potassium hydroxide pellets in addition to silica gel. The formula of this compound is determined by chemical analysis (table 1) and confirmed by refinement of the structure using the Rietveld method.

\section{$2.2 X$-ray studies}

The sample was mounted in the toploaded sample holder and investigated by X-ray powder diffraction (XRD). These samples were mounted in the top-loaded sample holders and investigated by X-ray powder diffraction technique (XRD). Powder X-ray diffraction data were collected at room temperature using a PANalytical X'pert-Pro diffractometer equipped with an ultrafast X'celerator detector. Ni-filtered $\mathrm{Cu} K_{\alpha}$ X-ray $(40 \mathrm{kV} / 40 \mathrm{~mA})$ were used. In order to limit the axial divergence, 0.02 rad primary and secondary Soller slits were inserted. Data were collected by continuous scan from 10 to $120^{\circ} 2 \theta$ with an effective step size of 0.016 and $20 \mathrm{~s}$ integration time per step. It is noted that the position sensitive $X^{\prime}$ 'celerator detector has an opening angle of $2.122^{\circ}$ with 127 channels. Prior to data analysis, the experimental data were recalculated to step sizes of $0.016^{\circ}$ using a cubic spline interpolation method. Indexing was performed using DICVOL04 software ${ }^{10}$ with standard options confidence factors of $\mathrm{M}(20)=$ 41 and $\mathrm{F}(20)=33.8 .{ }^{11}$ Our assumption was subsequently confirmed by successful Rietveld refinement of the investigated structure.

The X-ray powder diffraction data were refined by the Rietveld method ${ }^{12}$ using the FULLPROF code. ${ }^{13}$ The Rietveld refinement was carried out using the pseudo-Voigt function ${ }^{14}$ for the simulation of the peak shapes. Le Bail profile refinement was first used to

Table 1. Results of chemical analysis for $\left[\mathrm{Cs}_{0.92}\left(\mathrm{NH}_{4}\right)_{0.08}\right]_{2} \mathrm{TeCl}_{4} \mathrm{Br}_{2}$.

\begin{tabular}{lccccc}
\hline & $\mathrm{Te}(\%)$ & $\mathrm{Cl}(\%)$ & $\mathrm{Br}(\%)$ & $\mathrm{N}(\%)$ & $\mathrm{Cs}(\%)$ \\
\hline Calculated & 18.85 & 20.96 & 23.62 & 0.42 & 36.15 \\
Experimental & $19.11^{\mathrm{a}}$ & $20.25^{\mathrm{b}}$ & $23.72^{\mathrm{b}}$ & $0.48^{\mathrm{c}}$ & $37.23^{\mathrm{d}}$ \\
\hline
\end{tabular}

a Determined gravimetrically by reduction with $\left(\mathrm{SO}_{2}\right)$ to the element Te. ${ }^{20}$

${ }^{b}$ Determined by potentiometric method.

${ }^{\mathrm{c}}$ Determined by a Kjeldahl apparatus method.

${ }^{\mathrm{d}}$ Determined using a flame photometer. find the profile and instrumental parameters such as the zero-angle displacement error and asymmetry effects. The background was fitted with a linear interpolation between the 30 given points. ${ }^{15}$ The refinement with halfwidth parameters $U, V, W$, unit cell parameters mixing coefficient and the symmetry parameters converged to $\chi^{2}=0.059$. Then, the assumed structure was refined while fixing the profile and instrumental parameters. The refinement of $\mathrm{Br}$ and $\mathrm{Cl}$ in the same positions diverges and is not stable. For this reason, the $\mathrm{Cl}$ and $\mathrm{Br}$ atoms are fixed in two different positions and then they are ordered.

A final refinement taking into account the overall isotropic displacement factor ( $B \mathrm{ov}$ ) converged to $R_{P}=$ $0.093, R_{\text {wp }}=0.076$, and $R_{\text {bragg }}=0.018$ (table 2). Low values of the profile residuals, $R \mathrm{p}$ and $R \mathrm{wp}$, indicate a high background level rather than the real profile agreement, but low $R_{\mathrm{B}}$ values (which are not affected by the background level) show the reasonable agreement between the experimental and theoretical structural models. The occupancy probability of the Cs and $\mathrm{N}$ atoms was refined in such a way that the total occupancy was equal to 1 (table 3 ).

Crystal structure data and experimental conditions are collected in table 2. Positional and isotropic thermal parameters of the ternary halides $\left[\mathrm{Cs}_{0.92}\left(\mathrm{NH}_{4}\right)_{0.08}\right]_{2}$ $\mathrm{TeCl}_{4} \mathrm{Br}_{2}$ are summarised in table 3 . Figure 1 illustrates the final Rietveld plots for $\left[\mathrm{Cs}_{0.92}\left(\mathrm{NH}_{4}\right)_{0.08}\right]_{2} \mathrm{TeCl}_{4} \mathrm{Br}_{2}$.

Table 2. Crystal structure data and experimental conditions of structure determination of $\left[\mathrm{Cs}_{0.92}\left(\mathrm{NH}_{4}\right)_{0.08}\right]_{2} \mathrm{TeCl}_{4} \mathrm{Br}_{2}$.

Formula $\left[\mathrm{Cs}_{0.92}\left(\mathrm{NH}_{4}\right)_{0.08}\right]_{2} \mathrm{TeCl}_{4} \mathrm{Br}_{2}$

Temperature (K)

Space group

$a(\AA)$

$c(\AA)$

$V\left(\AA^{3}\right)$

$Z$

$D_{x}\left(\mathrm{gcm}^{-3}\right)$

Radiation $(\AA)$

Diffractometer

$2 \theta$ range of refinement $\left(^{\circ}\right)$

Number of structural variables ${ }^{\mathrm{a}}$

Number of global parameters ${ }^{b}$

$R_{P}$

293

P4/mnc

7.452(1)

$10.5440(3)$

$585.5652(3)$

2

3.83

$\mathrm{Cu}\left(\mathrm{K}_{\alpha 1}\right)=1.54060$,

$\mathrm{Cu}\left(\mathrm{K}_{\alpha 2}\right)=1.54433$

PANalytical X'pert-Pro

$10-120$

7

38

0.093

$R_{w p}$

0.076

0.059

$\chi^{2}$

0.018

${ }^{a}$ Including the scale factor.

${ }^{\mathrm{b}}$ Including background coefficients, cell parameters, Pseudo-

Voigt function parameters, and asymmetry parameters. 
Table 3. Positional equivalent and isotropic thermal parameters for the structure of $\left[\mathrm{Cs}_{0.92}\left(\mathrm{NH}_{4}\right)_{0.08}\right]_{2} \mathrm{TeCl}_{4} \mathrm{Br}_{2}$.

\begin{tabular}{lcccccc}
\hline Atoms & Site & $\mathrm{x}$ & $\mathrm{y}$ & $\mathrm{z}$ & $\mathrm{B}_{\text {iso }}\left(\AA^{2}\right)$ & Occ. factor \\
\hline \multicolumn{2}{c}{$\left[\mathrm{Cs}_{0.92}\left(\mathrm{NH}_{4}\right)_{0.08}\right]_{2} \mathrm{TeCl}_{4} \mathrm{Br}_{2}$} & & & & \\
$\mathrm{Te}$ & $2 \mathrm{~b}$ & $1 / 2$ & $1 / 2$ & 0 & 0.52951 & 1 \\
$\mathrm{Cs}$ & $4 \mathrm{~d}$ & 0 & $1 / 2$ & $1 / 4$ & $1.78147(10)$ & $0.920(4)$ \\
$\mathrm{N}$ & $4 \mathrm{~d}$ & 0 & $1 / 2$ & $1 / 4$ & $1.78147(10)$ & $0.080(4)$ \\
$\mathrm{Br}$ & $4 \mathrm{e}$ & 0 & 0 & $0.2518(1)$ & $0.7206(13)$ & 1 \\
$\mathrm{Cl}$ & $8 \mathrm{~h}$ & $0.7639(4)$ & $0.2733(8)$ & 0 & $0.3232(8)$ & 1 \\
$\mathrm{H}$ & $16 \mathrm{i}$ & 0 & 0.4380 & 0.1800 & 0.82744 & 0.020 \\
\hline
\end{tabular}

\subsection{Thermal behaviour}

DTA/TGA measurements were carried out on 5-10 mg samples at a heating rate of $10 \mathrm{~K} . \mathrm{min}^{-1}$ using a PerkinElmer TGA7 instrument. The analysis was conducted in the temperature range of $300-900 \mathrm{~K}$ in a nitrogen atmosphere under a constant flow rate of $20 \mathrm{ml} \cdot \mathrm{min}^{-1}$.

Differential scanning calorimetry (DSC) measurements at low temperature were carried out using a Perkin-Elmer DSC7 calorimeter in the temperature range from $120 \mathrm{~K}$ to $300 \mathrm{~K}$ at a heating rate of $10 \mathrm{~K} \cdot \mathrm{min}^{-1}$ using a polycrystalline sample in a flowing nitrogen atmosphere.

\subsection{Spectroscopy analysis}

The spectroscopy FTIR at room temperature was used to confirm the presence of the different vibration mode of ammonium ion in our compound. $\mathrm{KBr}$ pellets containing the new sample was prepared and the FTIR spectra recorded using a Perkin-Elmer 1750 spectrophotometer.
To complete the results of thermal behaviour and the FTIR spectroscopy, the new mixed compound was analysed by Raman spectra at different temperatures. Raman spectra of sample in sealed glass cell $(2 \mathrm{~mm}$ in diameter), were obtained between $120 \mathrm{~K}$ and $450 \mathrm{~K}$ with a Horibo Jobin Yvan HR800 microcomputer system instrument using a conventional scanning Raman instrument equipped with a Spex 1403 double monochromator (with a pair of 600 grooves $/ \mathrm{mm}$ gratings) and a Hamamatsu 928 photomultiplier detector. The excitation radiation was provided by coherent radiation with an $\mathrm{He}-\mathrm{Neon}$ laser at a wavelength of $633 \mathrm{~nm}$, and the output laser power was $50 \mathrm{~mW}$. The spectral resolution, in terms of slit width, varied from 3 to $1 \mathrm{~cm}^{-1}$.

\section{Results and discussion}

\subsection{Structure description}

The crystal structures of the $\mathrm{A}_{2} \mathrm{BX}_{6}$ usually belong to the large family of $\mathrm{K}_{2} \mathrm{PtCl}_{6}$ (the so-called antifluorite structure). For a tetragonally distorted $\mathrm{K}_{2} \mathrm{PtCl}_{6}$

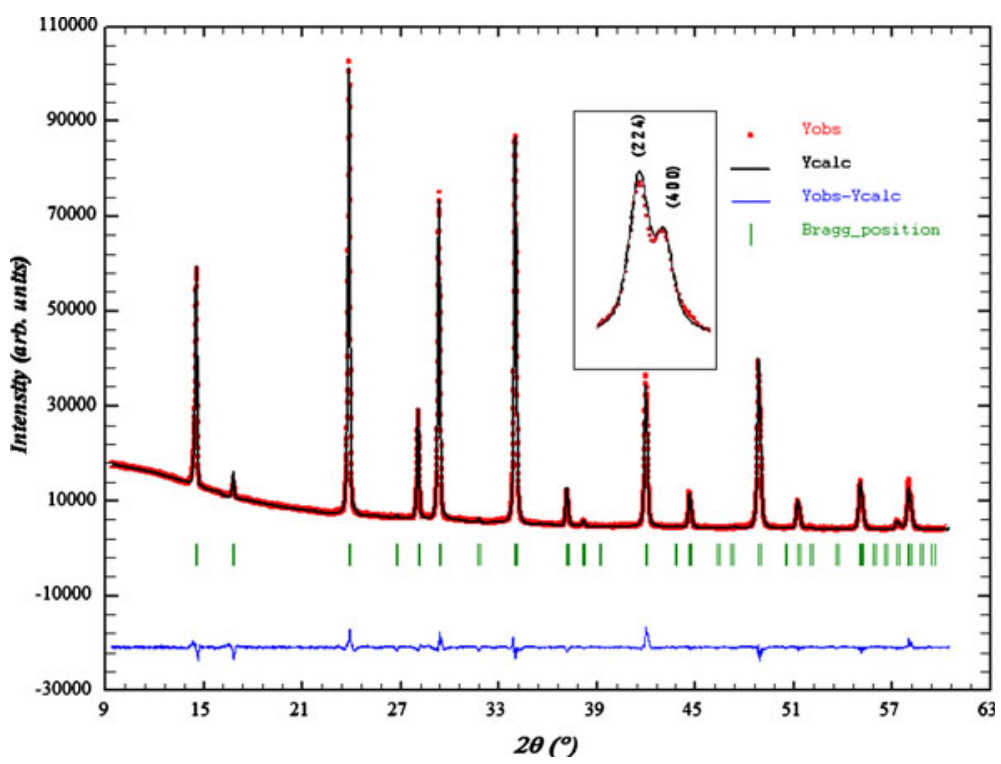

Figure 1. X-ray powder diffraction pattern and refinement of $\left[\mathrm{Cs}_{0.92}\left(\mathrm{NH}_{4}\right)_{0.08}\right]_{2} \mathrm{TeCl}_{4} \mathrm{Br}_{2}$. 


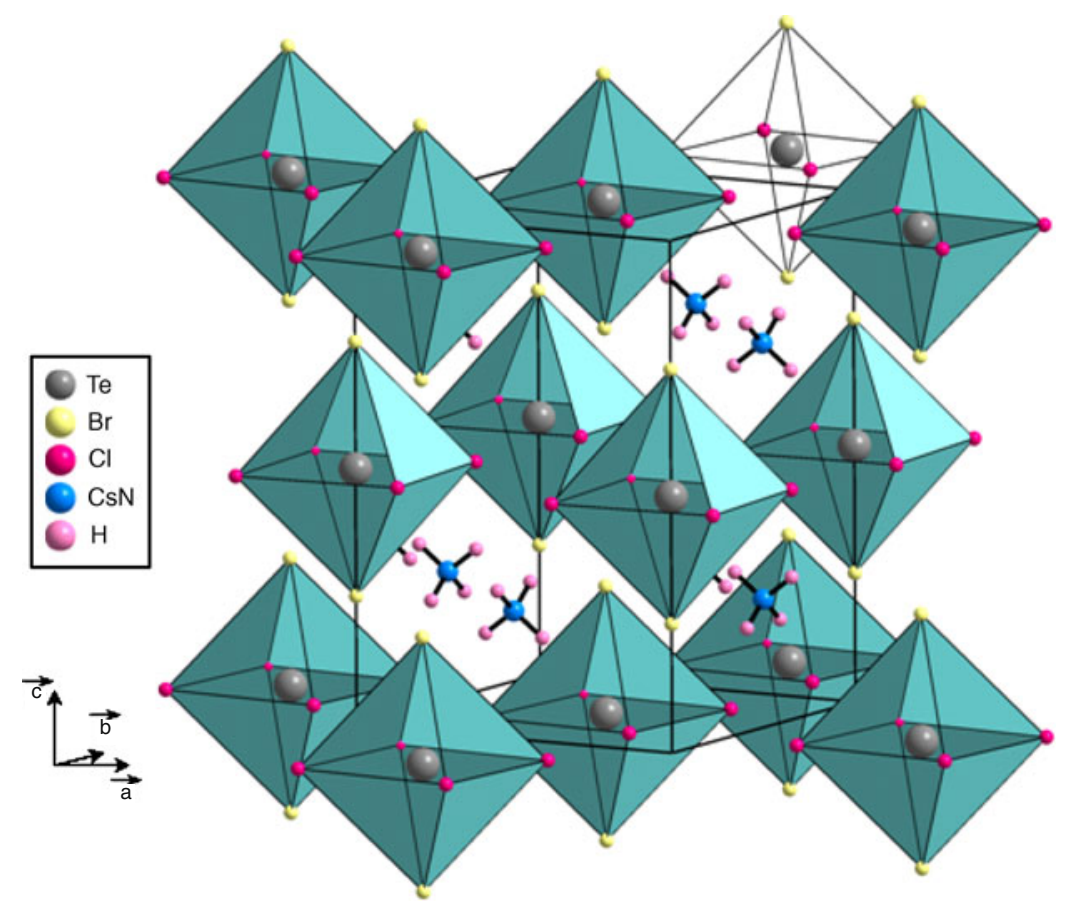

Figure 2. The structure of $\left[\mathrm{Cs}_{0.92}\left(\mathrm{NH}_{4}\right)_{0.08}\right]_{2} \mathrm{TeCl}_{4} \mathrm{Br}_{2}$.

type structure the space group $\mathrm{P} 4 / \mathrm{mnc}$ was first proposed by Das and Brown, reporting a low temperature phase of $\left(\mathrm{NH}_{4}\right)_{2} \mathrm{TeBr}_{6} .{ }^{16}$ In the present work, $\left[\mathrm{Cs}_{0.92}\left(\mathrm{Nh}_{4}\right)_{0.08}\right]_{2} \mathrm{TeCl}_{4} \mathrm{Br}_{2}$ crystallizes in the tetragonal space group $(\mathrm{P} 4 / \mathrm{mnc})$ with $\mathrm{a}=7.452(1) \AA, \mathrm{c}=$

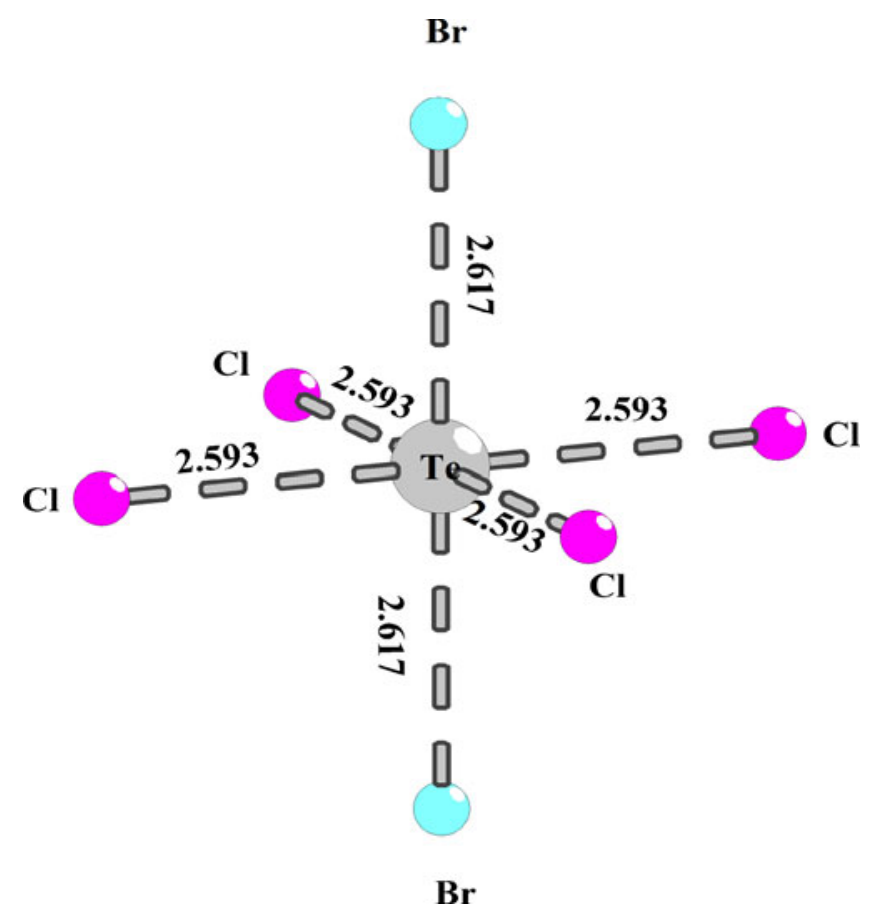

Figure 3. Tellurium environment in $\left[\mathrm{Cs}_{0.92}\left(\mathrm{NH}_{4}\right)_{0.08}\right]_{2}$ $\mathrm{TeCl}_{4} \mathrm{Br}_{2}$.
10.544(3) $\AA$, at room temperature. The Te atoms lie on the 2(b) sites surrounded by an octahedron of chlorine and bromine) atoms in the 4(e) positions with coordinates $(0,0, \mathrm{z})$ and $\mathrm{z}=0.25179(11)$ for $\mathrm{Br}$ and in the $8(\mathrm{~h})$ positions with coordinates $(\mathrm{x}, \mathrm{y}, 0)$ and $\mathrm{x}=0.7640(3)$, $\mathrm{y}=0.27337(8)$ for $\mathrm{Cl}$. The Cs or $\mathrm{N}$ atoms occupy the 4 (d) $(0,1 / 2,1 / 4)$ sites, as shown in figure 2 . The cohesion of the atomic arrangement is ensured by hydrogen and ionic bonding $\left(\mathrm{N}-\mathrm{H} . . \mathrm{Cl} / \mathrm{Br}\right.$ and $\left.\mathrm{Cs}^{+}-\mathrm{Cl}^{-} / \mathrm{Br}^{-}\right)$.

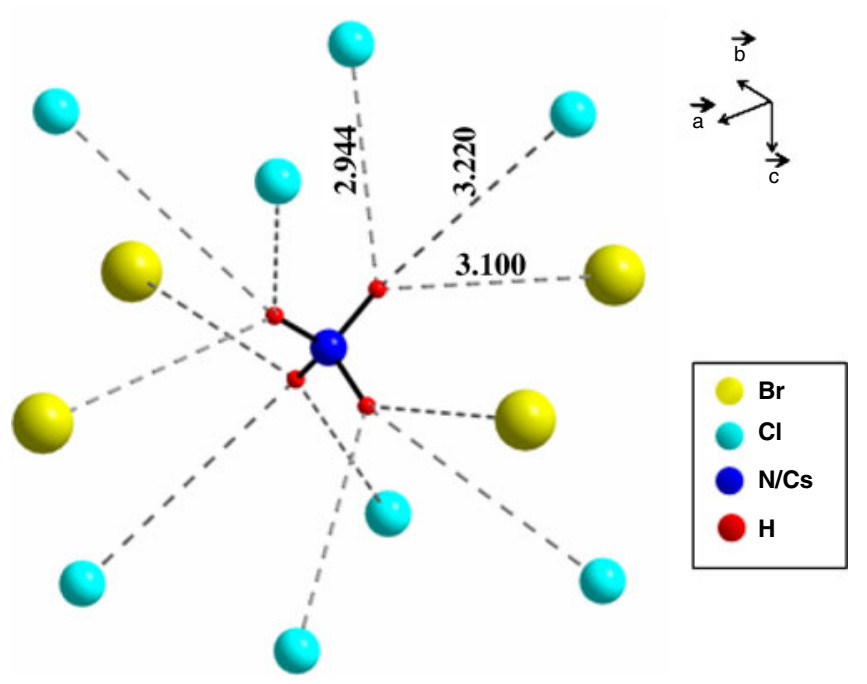

Figure 4. Ammonium environment with the different possibility of hydrogen bond in $\left[\mathrm{Cs}_{0.92}\left(\mathrm{NH}_{4}\right)_{0.08}\right]_{2} \mathrm{TeCl}_{4} \mathrm{Br}_{2}$. 




Figure 5. Projection along the four-fold axis with an anti-ferrorotative displacement of the $\left[\mathrm{TeCl}_{4} \mathrm{Br}_{2}\right]^{2-}$ octahedral: Show the hydrogen bond in compound $\left[\mathrm{Cs}_{0.92}\left(\mathrm{NH}_{4}\right)_{0.08}\right]_{2} \mathrm{TeCl}_{4} \mathrm{Br}_{2}$.

Each Te atom is surrounded by four chlorine and two bromine atoms forming a slightly distorted octahedron with distances $\mathrm{Te}-\mathrm{Cl}$ is $2.596(12) \AA$ and $\mathrm{Te}-\mathrm{Br}$ is 2.617(15) ̊ (figure 3). The small differences of $\mathrm{Te}-\mathrm{Br}$ and $\mathrm{Te}-\mathrm{Cl}$ bond lengths in the mixed compound are not significant considering the standard deviations and are typical for a tetragonal refinement of positional parameters. So the point symmetry of the $\mathrm{Te}\left(\mathrm{Cl}_{4} / \mathrm{Br}_{2}\right)^{2-}$ ion is still $\mathrm{m} 3 \mathrm{~m}$. There appears to be no stereochemical active lone pair of electrons at Te (IV) in this hexahalogeno complex ion.

We note, that for $\left[\mathrm{Cs}_{0.92}\left(\mathrm{NH}_{4}\right)_{0.08}\right]_{2} \mathrm{TeCl}_{4} \mathrm{Br}_{2}$, the TeBr distances vary, at most $0.064 \AA$ from $\left(\mathrm{NH}_{4}\right)_{2} \mathrm{TeBr}_{6}{ }^{16}$

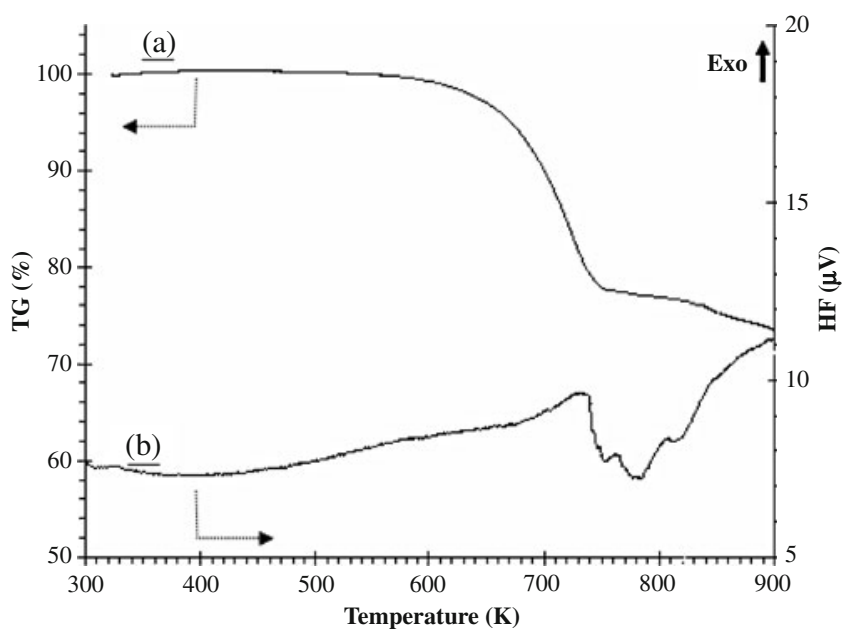

Figure 6. (a): Thermogravimetric (TG) and (b): differential thermal analysis (DTA) of $\left[\mathrm{Cs}_{0.92}\left(\mathrm{NH}_{4}\right)_{0.08}\right]_{2} \mathrm{TeCl}_{4} \mathrm{Br}_{2}$. structure to $0.078 \AA$ from $\mathrm{Cs}_{2} \mathrm{TeBr}_{6}{ }^{7}$ structure and the $\mathrm{Te}-\mathrm{Cl}$ distances vary, at less $0.015 \AA$ from $\left(\mathrm{NH}_{4}\right)_{2} \mathrm{TeCl}_{6}{ }^{17}$ structure to $0.085 \AA$ from $\mathrm{Cs}_{2} \mathrm{TeCl}_{6}{ }^{18}$ structure.

For $\left[\mathrm{Cs}_{0.92}\left(\mathrm{NH}_{4}\right)_{0.08}\right]_{2} \mathrm{TeCl}_{4} \mathrm{Br}_{2}$, in the tetragonal structure each monovalent cation $\left(\mathrm{Cs}^{+} / \mathrm{NH}_{4}^{+}\right)$is coordinated by 12 anions (figure 4): $8 \mathrm{Cl}$ atoms at distances ranging from 3.621(7) $\AA$ to 3.836(6) $\AA$ and $4 \mathrm{Br}$ atoms at distances equal to $3.728(4) \AA$. The $\mathrm{Cs}^{+} / \mathrm{NH}_{4}^{+}$groups are located between the $\mathrm{TeCl}_{4} \mathrm{Br}_{2}$ octahedra ensuring the stability of the structure by ionic and hydrogen bonding contacts $\left(\mathrm{Cs}^{+}\right)-\mathrm{Cl}^{-} / \mathrm{Br}^{-}$and $\mathrm{N}-\mathrm{H}-\mathrm{Cl} / \mathrm{Br}$, respectively.

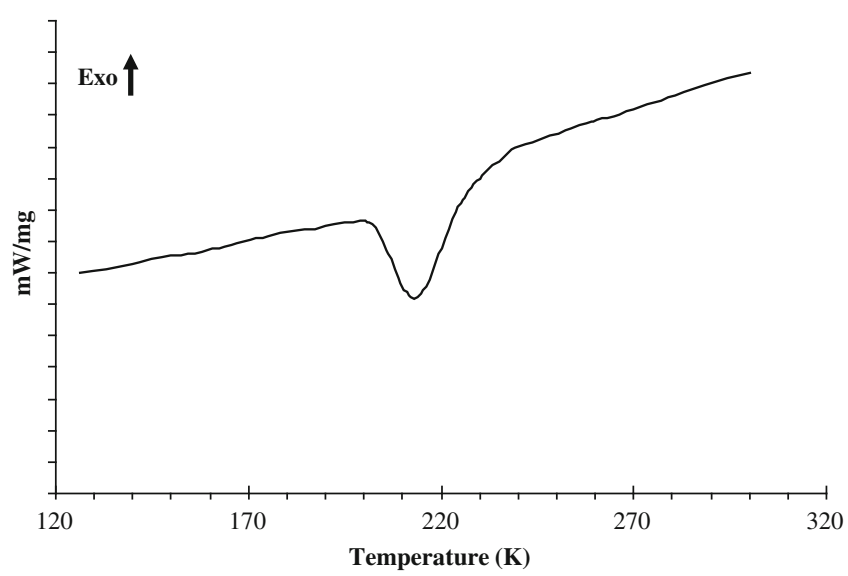

Figure 7. DSC thermogram of $\left[\mathrm{Cs}_{0.92}\left(\mathrm{NH}_{4}\right)_{0.08}\right]_{2} \mathrm{TeCl}_{4} \mathrm{Br}_{2}$ in the temperature range of 120 to $320 \mathrm{~K}$. 
The hydrogen atoms were located geometrically in the site symmetry $4 / \mathrm{m}$. All the hydrogen atoms of $\mathrm{NH}_{4}^{+}$are involved with the atoms of bromine and chlorine octahedra $\left(\mathrm{TeBr}_{2} \mathrm{Cl}_{4}\right)$ to form a three-dimensional network of hydrogen bonds with the ionic cohesion of the crystal lattice (figure 5). The $\mathrm{Br}$ atom enters into hydrogen bond $\mathrm{H}$....Br with distance equal to 3.100 (6) $\AA$. But, the $\mathrm{H}$ bond length $\mathrm{H}$... Cl is in the order of 2.944(18) $\AA$ (figure 4). The difference in length of bond is the origin of the strong interaction $\mathrm{H}$... Cl compared to that of $\mathrm{H} . . . \mathrm{Br}$ due to the difference of the electronegativity between chlorine and bromine atoms.

\subsection{Thermal analysis}

Figure 6 presents the typical TG/DTA curves measured at a heating rate of $10 \mathrm{~K} \cdot \mathrm{min}^{-1}$. The DTA curve, obtained over a temperature range of 300-900 K, illustrates that there are a large endothermic process pointed at $780 \mathrm{~K}$. As is indicated by the TG curve, this peak is accompanied with a loss mass, implicating the decomposition of sample.

At low temperature, a transition from phase I to phase II was detected at $213 \mathrm{~K}$ by DSC (figure 7). This transition can be attributed to an order-disorder phase transition involving the hydrogen bonds coupled with the distortion of the octahedral. This result has been confirmed by Raman studies.

\subsection{Spectroscopic studies}

Raman and IR spectroscopy at room temperature were used to determine the different observed bands of the mixed compound $\left[\mathrm{Cs}_{0.92}\left(\mathrm{NH}_{4}\right)_{0.08}\right]_{2} \mathrm{TeCl}_{4} \mathrm{Br}_{2}$ and to confirm the tellurium coordination.

The FTIR spectral data and the band assignments of $\left[\mathrm{Cs}_{0.92}\left(\mathrm{NH}_{4}\right)_{0.08}\right]_{2} \mathrm{TeCl}_{4} \mathrm{Br}_{2}$ at room temperature are presented in table 4 , respectively. The intense absorption bands, at $3131 \mathrm{~cm}^{-1}$ and $1402 \mathrm{~cm}^{-1}$ are attributed to the triply degenerate vibrations, $v_{3}$ (stretching) and $v_{4}$ (deformation), respectively. The

Table 4. Observed IR frequencies $\left(\mathrm{cm}^{-1}\right)$ and band assignments for $\left[\mathrm{Cs}_{0.92}\left(\mathrm{NH}_{4}\right)_{0.08}\right]_{2} \mathrm{TeCl}_{4} \mathrm{Br}_{2}$ at room temperature.

\begin{tabular}{ll}
\hline Frequencies $\left(\mathrm{cm}^{-1}\right)$ & \multicolumn{1}{c}{ Assignments } \\
\hline $1402 \mathrm{vs}$ & $v_{4}\left(\mathrm{NH}_{4}\right)$ (Deformation) \\
$1606 \mathrm{~s}$ & $v_{2}\left(\mathrm{NH}_{4}\right)$ (Deformation) \\
$2823 \mathrm{vw}$ & $2 v_{4}\left(\mathrm{NH}_{4}\right)$ \\
$3012 \mathrm{w}$ & $v_{2}+\mathrm{v}_{4}\left(\mathrm{NH}_{4}\right)$ \\
$3131 \mathrm{vs}$ & $v_{3}\left(\mathrm{NH}_{4}\right)($ Stretching)
\end{tabular}

Relative intensities: vs, very strong; s, strong; w, weak; vw, very weak. band at $1606 \mathrm{~cm}^{-1}$ corresponds to $v_{2}$ deformation mode. Other bands corresponding to interactions between these fundamental vibrations (i.e., overtones and combination bands) are observed at $3012 \mathrm{~cm}^{-1}\left(v_{2}+v_{4}\right)$ and $2823 \mathrm{~cm}^{-1}\left(2 v_{4}\right) .{ }^{19}$

At room temperature, the Raman spectrum of the mixed compound $\left[\mathrm{Cs}_{0.92}\left(\mathrm{NH}_{4}\right)_{0.08}\right]_{2} \mathrm{TeCl}_{4} \mathrm{Br}_{2}$ is quite resolved, which confirms the presence of the polar phase. The structure of the $\left[\mathrm{Cs}_{0.92}\left(\mathrm{NH}_{4}\right)_{0.08}\right]_{2} \mathrm{TeCl}_{4} \mathrm{Br}_{2}$ is characterized by the existence of the octahedral $\mathrm{TeX}_{6}^{2-}$ anions $(\mathrm{X}: \mathrm{Cl} / \mathrm{Br})$, The interesting feature of the new mixed compound is the coexistence of two types of bands corresponding to the vibrational modes of Te$\mathrm{Cl}$ and $\mathrm{Te}-\mathrm{Br}$. The ordering of these two modes of vibrations as well as the dynamics of the $\mathrm{NH}_{4}^{+}$groups determines the properties of this sample.

Figure 8 presents the Raman spectra of the $\left[\mathrm{Cs}_{0.92}\left(\mathrm{NH}_{4}\right)_{0.08}\right]_{2} \mathrm{TeCl}_{4} \mathrm{Br}_{2}$ sample. By comparing with pure compounds, ${ }^{18}$ the Raman spectra can be divided into different spectral frequency ranges and lines: from $210-310 \mathrm{~cm}^{-1}$ the bands can be assigned to the Te-Cl stretching modes $\left(v_{1}\right.$ and $\left.v_{2}\right)$, the range from 170 to $210 \mathrm{~cm}^{-1}$ can be assigned to symmetric $\mathrm{Te}-\mathrm{Br}$ stretching vibrations $\left(v_{1}\right.$ and $v_{2}$ ) and the Raman lines observed at $131 \mathrm{~cm}^{-1}$ and $160 \mathrm{~cm}^{-1}$ are associated respectively to $\mathrm{Te}-\mathrm{Br}$ and $\mathrm{Te}-\mathrm{Cl}$ bending vibration $\left(v_{5}\right)$. The line observed at $115 \mathrm{~cm}^{-1}$ is attributed to the liberations mode of $\mathrm{NH}_{4}^{+}$and the range from 50 to $100 \mathrm{~cm}^{-1}$ can be attributed to the presence of the translation modes of $\mathrm{Cs}^{+}$and $\mathrm{NH}_{4}^{+}$.

In the present work, we would like to concentrate on thermal changes of the frequencies of symmetrical bending vibrations of the $\mathrm{Te}-\mathrm{Cl}$ (intense band at $130 \mathrm{~cm}^{-1}$ accompanied with a broad band at $127 \mathrm{~cm}^{-1}$ ) and the symmetric bending vibrations of $\mathrm{Te}-\mathrm{Br}$ (at $160 \mathrm{~cm}^{-1}$ ) as well as frequencies of librations and translation modes of $\mathrm{NH}_{4}^{+}$(band at $115 \mathrm{~cm}^{-1}$ and $91 \mathrm{~cm}^{-1}$, respectively).

By increasing temperature, the sample passes from phase I to phase II. In fact, as one can see the Raman spectra change significantly at $\mathrm{T}=213 \mathrm{~K}$. Below this temperature the Raman lines which are related to $v_{5} \mathrm{Te}-$ $\mathrm{Cl}$ vibrations split into two well-developed distinct lines $\left(\sim 127\right.$ and $\left.130 \mathrm{~cm}^{-1}\right)$. The lines which are assigned to $v_{5}$ Te-Br vibration $\left(\sim 160 \mathrm{~cm}^{-1}\right)$ do not exhibit changes in their shape but the positions of this bands undergo significant changes at $\mathrm{T}=213 \mathrm{~K}$. The bands relative to $v_{1}(\mathrm{TeCl})$, at 285,277 and $268 \mathrm{~cm}^{-1}$ decrease in intensity on raising the temperature and the last one at $268 \mathrm{~cm}^{-1}$ disappears after the phase transition detected by $\mathrm{DSC}$ at $213 \mathrm{~K}$. On the other hand, the $v_{2}(\mathrm{TeCl})$ bands which appear at 245 and $235 \mathrm{~cm}^{-1}$ decrease in intensity and becomes very broad. The bands at 


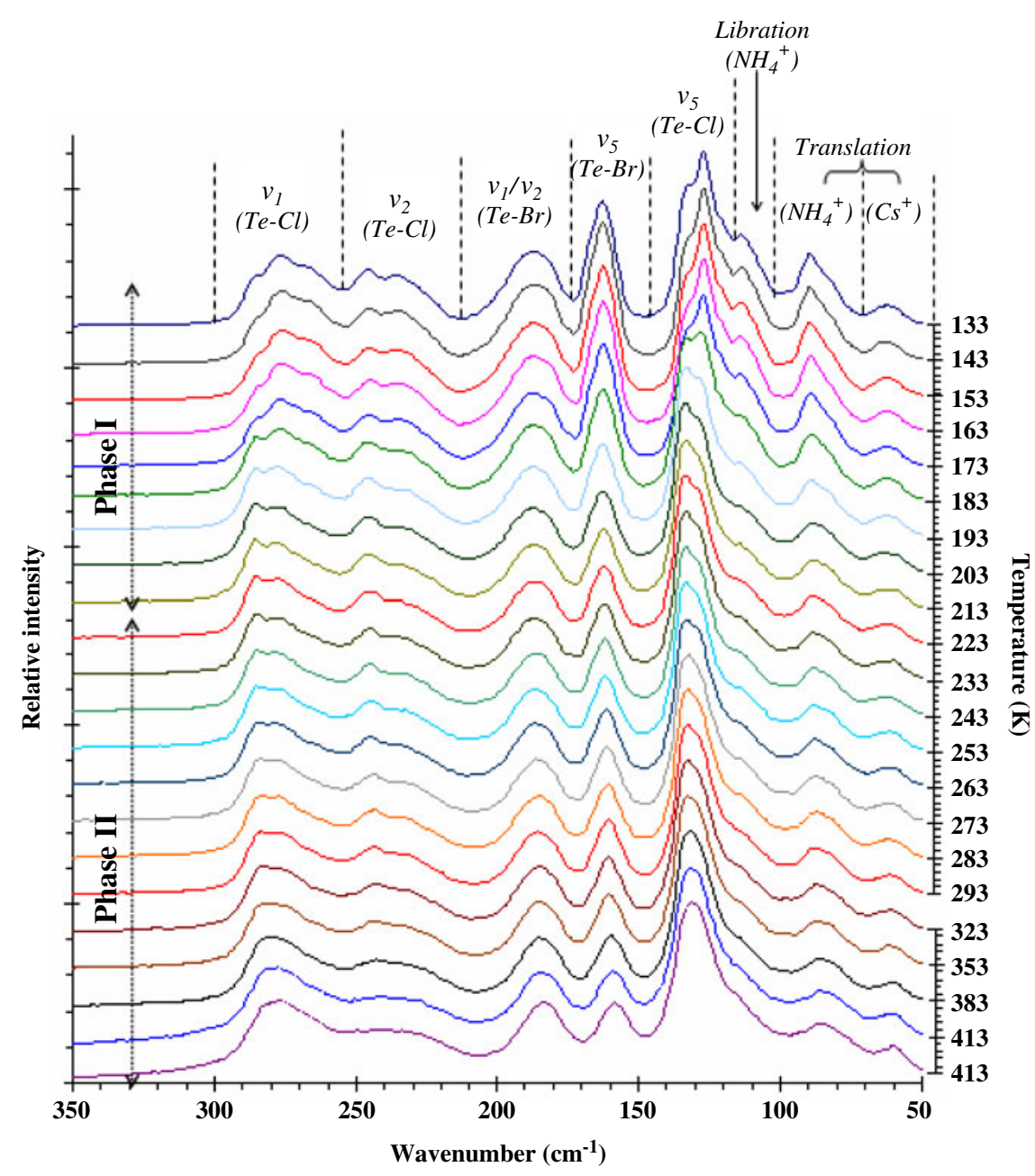

Figure 8. Raman spectra of $\left[\mathrm{Cs}_{0.92}\left(\mathrm{NH}_{4}\right)_{0.08}\right]_{2} \mathrm{TeCl}_{4} \mathrm{Br}_{2}$ at different temperatures.

$91 \mathrm{~cm}^{-1}, 60 \mathrm{~cm}^{-1}$ and $188 \mathrm{~cm}^{-1}$ decrease in intensity and broaden as the temperature is increased. Other than this, the peak observed at $115 \mathrm{~cm}^{-1}$ decreases in intensity on raising the temperature and disappears after the temperature $\mathrm{T}=213 \mathrm{~K}$, indicate the large dynamic motion of $\mathrm{NH}_{4}^{+}$at phase II.

\section{Conclusion}

The results of detailed XRD, low temperature Raman and DSC studies of the new substituted $\left[\mathrm{Cs}_{0.92}\left(\mathrm{NH}_{4}\right)_{0.08}\right]_{2} \mathrm{TeCl}_{4} \mathrm{Br}_{2}$ are presented. The title compound crystallises in $\mathrm{P} 4 / \mathrm{mnc}$ tetragonal space group. The main feature of the structure of this material is based on isolated $\mathrm{TeX}_{6}(\mathrm{X}=\mathrm{Cl}$ or $\mathrm{Br})$ octahedra connected by ionic and hydrogen bonding through the Cs or $\mathrm{N}$ atoms which are located between the octahedral $\mathrm{TeX}_{6}$ units ensuring the stability of the structure. The Raman spectra $\left(50-350 \mathrm{~cm}^{-1}\right)$ of powder sample was studied at temperature ranging from 120 to $400 \mathrm{~K}$. The thermal evolution of the Raman spectra reveals an orderdisorder phase transition at about $213 \mathrm{~K}$ involving the hydrogen bonds coupled with the distortion of the octahedral. Moreover, DSC measurement in the temperature range $(120-300 \mathrm{~K})$ was also presented. The occurrence of a low-temperature phase transition near $213 \mathrm{~K}$ is well-evidenced.

Low temperature XRD and luminescence measurements investigations of the title compound are in our future study in order to confirm the nature of transformation observed by DSC and Raman and to know the influence of distortion of the Te(IV) coordination octahedron on its luminescence.

\section{References}

1. Gillespie R J and Nyholm R S 1957 Quart. Rev. 11339

2. Barrier N, Rueff J M, Lepetit M B, Contreras-Garcia J, Malo S and Raveau B 2009 Solid State Sci. 11289 
3. Zhang S, Huang Y, Shi L, Qiao X and Seo H J 2009 Physica B. $\mathbf{4 0 4} 4136$

4. Gaitan M, Jerez A, Pico C and Veiga M L 1987 Mat. Res. Bull. 22(4) 477

5. Loukil M, Ben Salah A and Kabadou A 2010 J. Alloys Compd. L10 488

6. Brown I D 1964 Canad. J. Chem. 422758

7. Das A K and Brown I D 1966 Canad. J. Chem. 44939

8. Berg R W and Nielsen K 1979 Acta Chem. Stand. A33 157

9. Abriel W 1982 Z. Kristallogr. 1159

10. Louër D and Louër M 1972 J. Appl. Crystallogr. 5271

11. Boultif A and Louër D 2004 J. Appl. Crystallogr. 37724

12. Rietveld H M 1969 J. Appl. Crystallogr. 265
13. Rodriguez-Carjaval $1990 \mathrm{~J}$. Proceedings of the satellite meeting on powder diffraction $\mathbf{1 2 7}$

14. Young R A and Wiles D B 1982 J. Appl. Crystallogr. 15 430

15. Roisnel T 2001 Fullprof Rietveld-Juan RodriguezCarvajal and Win-Plotr Interface.

16. Das A K and Brown I D 1969 Canad. J. Chem. 474288

17. Nakamoto K 1963 Infrared spectra of inorganic, coordination compounds (New York; Singapore: Wiley)

18. Berg R W, Poulsen FW and Bjerrum N J 1977 J. Chem. Phys. 67(5) 1829

19. Engel G 1933 Naturwissenschaften 21704

20. Williams L R and Haskett P 1969 Anal. Chem. 411138 